\section{Deimplementing arthroscopy, improving concussion reporting and celebrating research quality}

\author{
Karim M Khan
}

As we say on the British Journal of Sports Medicine (BJSM) podcast-thanks for choosing to engage with BJSM. Your worldwide author team brings you the full spectrum sport and exercise medicine, sports physiotherapy, as well as sports science in this $22 \mathrm{nd}$ of our 24 annual issues.

Three articles relate to arthroscopy: the Finnish Degenerative Meniscal Lesion Study (FIDELITY) knee surgery randomised controlled trial (RCT) (see page 1332) was a landmark because it: (i) included a sham surgery control group and, (ii) patients had an MRI-proven meniscal tear along with their symptoms and signs. These were classic patients for arthroscopy-classic in the sense that they very typically were slam-dunks for surgery. In the FIDELITY trial, sham surgery produced great results at 1 year (reported in the New England Journal of Medicine ${ }^{1}$ ) and that sham group continues to do well at 5 years as you can read here. They are doing just as well as the patients who underwent arthroscopic partial meniscectomy. Read two leading orthopaedic surgeons' take home messages-thank you Drs Lars Engebretsen (Norway) and Gordon Moatshe (Canada/Norway). (see page 1311). Respectfully, surgeons should listen to their colleagues here--and it seems as if they are (see issue cover image)

Is the 'Legend of arthroscopy' (eminence-based practice unsupported by RCTs) losing its shine? One of the stars of the sport and exercise clinical community-Dr Clare Ardern-in collaboration with Helsinki's Professor Teppo Jarvinen @ShamTeppo), highlight that arthroscopy rates are declining (see page 1312). The authors propose five reasons and their \#1 most likely is that trials such as FIDELITY mentioned earlier are making younger doctors challenge the dogma of outdated guidelines and fellowships.

Family Practice and Kinesiology, The University of British Columbia, Vancouver, British Columbia, Canada

Correspondence to Dr Karim M Khan, Family Practice \& Kinesiology, The University of British Columbia, Vancouver, British Columbia, Canada: karim.khan@ubc.ca

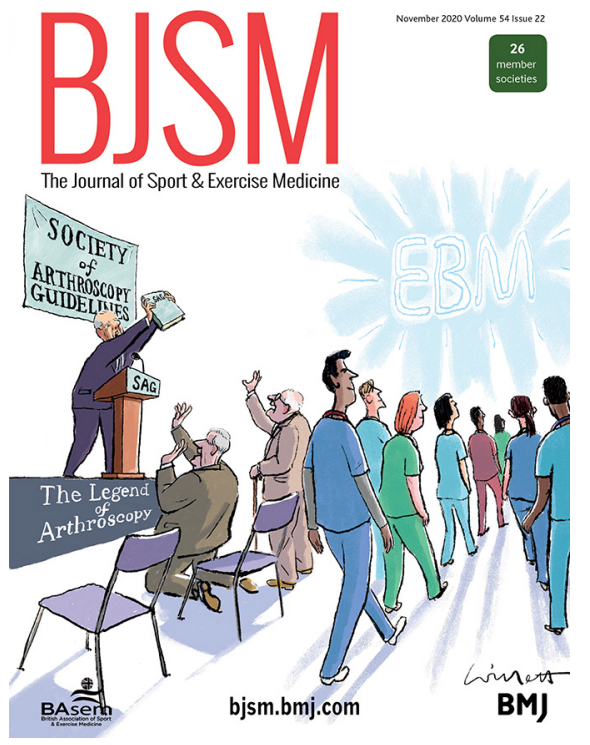

What's the clinical take home message about knee and shoulder arthroscopy from the three papers? If you are a nonsurgical clinician, such as a physiotherapist, sport and exercise medicine specialist, or primary care physician with a range of sports medicine training, you should not feel pressured into referring patients for a surgical opinion unless you think the time may be right for a certain subgroup of patients to consult a surgeon. Studies such FIDELITY (see previous discussion) and orthopaedic surgeon Dr Nina Kise's ${ }^{2}$ paper in The BMJ mean exercise therapy is the appropriate first-line management.

Side bar: Malcolm Willett has previously provided BJSM with cartoons in 2008, 2009 and in 2016. We have been privileged to have had that connection with a star of the BMJ community (and more!).

\section{ENOUGH OF KNEES: HELPING}

\section{ATHLETES DISCLOSE CONCUSSION}

Kudos to the very respected Seattle doctor Emily Kroshus for her role in the National Collegiate Athletics Association and the Department of Defence knowledge translation/implementation science/ scale-up study (see page 1314). These efforts to turn research, and consensus statements go by many names-I like implementation and scale-up when we are talking about implementation and scale-up. Even though words that end in 'ion' (implementation in this case) are 'zombie nouns'. ${ }^{3}$ This author provides an invaluable guide to help colleges (universities) and the military encourage athletes to disclose earlier. This paper is an editor's choice for this issue (free).

\section{METHODS MATTER}

I am delighted to guide you to methods papers from Aarhus, Dublin and Tehran (see pages 1307, 1365 and 1309). Quality control does not usually generate long lineups at the door of a conference session, but without quality methods, our profession is merely Mickey Mouse medicine. Kudos to the BJSM community for the many advances that folks have learnt from card-carrying statisticians (such as Dr Mohammad Ali Mansournia, Oxford graduate and sports medicine specialist in Tehran). Leadership of BJSM methods matters has come from Denmark (that's the Aarhus connection above) by associate professor Rasmus Nielsen. Follow him on Twitter@Runsafe_Rasmus. Here's the 2019 Methods Matter expert statement $^{45}$ copublished in both BJSM and the Journal of Orthopaedic and Sports Physical Therapy.

\section{Hearing a hamstring tear off}

'I heard it as much as I felt it' is certainly a tempting title for a paper about complete hamstring tear off the ischium. Boston's Michelle McKay, a senior American Express travel executive, shares her compelling story (see page 1373). She was fortunate, she believes, to benefit from the best of London sports medicine while on transfer from the Cradle of Liberty .

\section{LOOKING FORWARD}

Next month in BJSM, we eagerly anticipate another bumper issue from our Danish Sports Physiotherapy and Sports Medicine colleagues. Watch for details of the fourth World Congress on Sports PT in Nyborg, Denmark in August 2022-yes 2022.

Before that, however, BJSM will close 2020 with a spectacular World Health Organization physical activity Guideline Issue edited by Professor Emmanuel Stamatakis and the WHO's Professor Fiona Bull (MBE). 'That's a bingo!' as the now-classic movie line goes (https:// youtu.be/q5 pESPQpXxE; Inglorious Basterds, 2009) 
Keep an eye on your social media channels for full BJSM value: Twitter $75 \mathrm{~K}$ followers, Facebook $110 \mathrm{~K}$ likes, Instagram $50 \mathrm{~K}$ followers, $>8$ million views on the BJSM YouTube channel and over six million listens to the BJSM podcast (great via the mobile app). We hope you get the chance to have a physically active day!

Funding The authors have not declared a specific grant for this research from any funding agency in the public, commercial or not-for-profit sectors.

Competing interests None declared.

Patient consent for publication Not required.

Provenance and peer review Commissioned; internally peer reviewed. (c) Author(s) (or their employer(s)) 2020. No commercial re-use. See rights and permissions. Published by BMJ.

\section{(D) Check for updates}

To cite Khan KM. Br J Sports Med 2020;54:1305-1306.

Accepted 5 October 2020

Br J Sports Med 2020;54:1305-1306. doi:10.1136/bjsports-2020-103518

\section{ORCID iD}

Karim M Khan http://orcid.org/0000-0002-9976-0258

\section{REFERENCES}

1 Sihvonen R, Paavola M, Malmivaara A, et al. Arthroscopic partial meniscectomy versus sham surgery for a degenerative meniscal tear. $N$ Eng/ I Med 2013;369:2515-24.

2 Kise NJ, Risberg MA, Stensrud S, et al. Exercise therapy versus arthroscopic partial meniscectomy for degenerative meniscal tear in middle aged patients: randomised controlled trial with two year follow-up. BMJ 2016;354:i3740.

3 Shrout PE, Fleiss JL. Intraclass correlations: uses in assessing rater reliability. Psychol Bull 1979;86:420-8.

4 Nielsen RO, Shrier I, Casals M, et al. Statement on methods in sport injury research from the 1st methods matter meeting, Copenhagen, 2019. Br J Sports Med 2020;54:941.

5 Nielsen Rasmus Østergaard, Shrier I, Casals M, et al. Statement on methods in sport injury research from the first methods matter meeting, Copenhagen, 2019. J Orthop Sports Phys Ther 2020;50:226-33. 